\title{
Whose Children?: A Response to Professor Guggenheim
}

\section{Citation}

Elizabeth Bartholet, Whose Children?: A Response to Professor Guggenheim, 113 Harv. L. Rev. 1999 (2000).

\section{Permanent link}

http://nrs.harvard.edu/urn-3:HUL.InstRepos:3035332

\section{Terms of Use}

This article was downloaded from Harvard University's DASH repository, and is made available under the terms and conditions applicable to Other Posted Material, as set forth at http:// nrs.harvard.edu/urn-3:HUL.InstRepos:dash.current.terms-of-use\#LAA

\section{Share Your Story}

The Harvard community has made this article openly available.

Please share how this access benefits you. Submit a story.

\section{Accessibility}




\title{
BOOK REVIEWS
}

\author{
Reply \\ WHOSE CHILDREN? \\ A RESPONSE TO PROFESSOR GUGGENHEIM
}

\section{Elizabeth Bartholet*}

Martin Guggenheim's book review of Nobody's Children affirms his faith in family preservation and, not surprisingly, condemns my book, which he describes as "an unprecedented and extremely radical critique of child welfare practice." ${ }^{\prime}$ Unfortunately, Guggenheim's hostility to my basic message apparently blinded him to what the book actually says in spelling out that message. The result is a review that grossly mischaracterizes and distorts my positions. This response addresses only what I see as some of the most significantly misleading aspects of Guggenheim's review, to clarify in brief the positions I actually take in Nobody's Children. I do not try to correct all or even most of his misstatements, nor do I engage in a debate on the merits. Instead, I encourage readers interested in the issues to read the book for themselves and then to decide what they think.

\section{POVERTy, FAMILY SUPPORT, AND FAMILY PRESERVATION}

Professor Guggenheim merges and thereby fundamentally confuses what I have to say about three different kinds of programs that might usefully address problems of child maltreatment: general social reform programs directed at poverty and at social injustice, early-intervention family support programs, and late-stage family preservation programs. Like Guggenheim, I believe that poverty and social injustice are the root causes of most child maltreatment, and that fundamental social and economic reform would be the most effective approach to child maltreatment prevention. Like Guggenheim, I also believe that earlystage intervention programs designed to support at-risk parents and to help them avoid the problems that spawn child maltreatment are important. Unlike Guggenheim, however, I am critical of many aspects of the late-stage family preservation programs that work to keep chil-

\footnotetext{
- Professor of Law, Harvard Law School.

1 Martin Guggenheim, Somebody's Children: Sustaining the Family's Place in Child Welfare Policy, 113 HARV. L. REV. 1716, I 717 (2000) (reviewing ElIZABETH BaRTHOLET, NOBODY'S ChILDREn: ABUSE AND NegleCt, Foster DRIFT, AND the AdOPTION Alternative (r 999 )).
} 
dren who have been abused and neglected with the families responsible for this maltreatment. Guggenheim ignores most of what I say about the first two issues, and equates my criticism of late-stage family preservation programs with condemnation of all efforts to support and preserve families. ${ }^{2}$ This completely misconceives my position.

From the beginning to the end of Nobody's Children, I emphasize the centrality of the link between poverty and child maltreatment. ${ }^{3}$ Although Guggenheim implies that I view parents who abuse and neglect their children as inadequate or worthless people, ${ }^{4}$ I make clear throughout the book that $I$ in fact view them as victims - victims of social and economic injustice, who are very often victims of childhood abuse and neglect themselves. ${ }^{5}$ I do not subscribe to the view he attributes to me, that child maltreatment should be understood as a problem involving individual rather than social pathology. ${ }^{6}$ Like Guggenheim, I think society should provide more upfront support to families, and I decry the cutback in social services in recent decades. ${ }^{7}$ Guggenheim suggests that I see the "forcible removal of children from their families, and particularly the permanent banishment of birth relatives from their lives, as ... an outcome worthy of celebration." This is patently absurd. My book makes unmistakably clear that I believe, as he does, that society should do much more than it ever has to support families upfront so that such removal is unnecessary. And of course adoption does not necessarily mean, as Guggenheim knows, the "permanent banishment" of birth parents. There is a powerful trend toward maintaining ties between adopted children and their families of origin, especially where emotional bonds have developed prior to adoption. ${ }^{9}$

It is true that I do not devote the bulk of Nobody's Children to delineating a program for overall social reform, but that does not mean that I place a lower priority on such social reform than Guggenheim does. It is simply not my topic in this book. My topic instead involves children currently suffering abuse and neglect, and what we should do today and tomorrow to give them a chance at a decent life. My point is that however sympathetic we are to their parents, we should not al-

\footnotetext{
2 See, e.g., id. at $1717,1721,1728,1734,1735-36$.

3 See BARTHOLET, supra note I, at 233-43 (devoting an entire chapter to "Race, Poverty, and Historic Injustice"); see also id. at 4-6, 54-55.

4 See, e.g., Guggenheim, supra note I, at 1746 n.150.

5 See, e.g., BARTHOLET, supra note $\mathrm{I}$, at 6, 96, 226-27, 230, 233-34, 235-36.

6 See Guggenheim, supra note I, at 1737.

7 See, e.g., BARTHOLET, supra note 1 , at $34,36-37,54-55,99-100,235-36,238$. I never assume, as Guggenheim claims, that "society has tried everything possible to improve the conditions of poor children." Guggenheim, supra note I, at 1722 .

8 Guggenheim, supra note I, at 1750.

9 See BARTHOLET, supra note I, at 179.
} 
low these children to be further victimized, and we should not condemn them to the lives of so many who suffer abuse and neglect on an ongoing basis - lives characterized by homelessness, unemployment, alcohol and drug addiction, and abuse and neglect of their own children. I agree entirely with Guggenheim when he argues that adoption is not a solution for the social injustice at the root of child maltreatment, ${ }^{10}$ but I do think adoption can be an important solution for a large number of children. Requiring these children to grow up with parents who are incapable of parenting, or with "temporary" foster parents, does nothing, in my view, to solve underlying problems of injustice, although it may alleviate collective feelings of social guilt.

I devote substantial attention in Nobody's Children to earlyintervention family support programs, because I see such programs as a very important and positive form of family preservation. Indeed, the concept of early intervention is central to the book's organizing thesis. My argument is that the state should play a generally more activist role in the family by providing upfront increased support services aimed at enabling families to function successfully, and by being more willing to protect children from abuse and neglect when families break down. ${ }^{11}$ I focus on intensive home visitation as a particularly promising example of early intervention, devoting an entire chapter to it. Guggenheim ignores almost everything I say on this topic, and when he finally mentions my proposal, he mischaracterizes it. He claims that I would impose home visitors only on the "highest-risk families," 12 when in fact I stress the importance of not limiting such programs to the high risk population and argue instead for a "universal home visitation system."13

Thus, although Guggenheim is correct in describing me as a critic of late-stage family preservation programs, his attempt to paint me as a critic of all family support and preservation programs flies in the face of what any fair-minded reading of my book reveals. He is also off-base in his analysis of my critique of late-stage family preservation programs. I urge readers interested in the social science evidence related to the issue of whether these programs function adequately to protect children from ongoing abuse and neglect, to read for them-

\footnotetext{
10 See id. at 235-36 ("If we want truly to solve the child maltreatment problem we need to get at the root causes, which would mean to begin seriously to address issues of racism and economic inequality. It is no real solution to wait until some children have been identified as injured and then remove them to live with other families."); $f$. Guggenheim, supra note $I$, at 1738 .

11 See BARTHOLET, supra note 1 , at $163-204$ ("Promising New Directions and Traditional Pitfalls": Chapters 7 ("Intervening Early with Home Visitation") and 8 ("Taking Adoption Seriously")); see also id. at $238-40$.

12 Guggenheim, supra note 1 , at 1747 .

13 BARTHOLET, supra note 1 , at $171-74$.
} 
selves the case I make in Nobody's Children. ${ }^{14}$ One point is worth noting here, however. Advocates for family preservation programs have for years made claims for the success of these programs on the basis of an assumption that success should be defined by the goal of keeping children at risk for abuse and neglect in the families that victimized them. These advocates ignore the rather obvious point that a concern about children's welfare mandates an examination of whether children in such preserved families are subject to ongoing abuse and neglect. ${ }^{15}$ The research indicates that they are. ${ }^{16}$ Not only does Guggenheim ignore this point, but his review exemplifies the problem I try to illuminate, as he too makes claims for the proven "success" of family preservation programs in terms of their ability to prevent child removal. ${ }^{17}$

\section{MALTREATMENT: ABUSE AND NEGLECT}

Central to my discussion of the nature of the current child maltreatment problem is my claim that child neglect must be understood as just as important as child abuse, if not more important. I argue that today's neglect cases are typically cases in which children simply do not receive the active nurturing that all children need, cases in which parents are often trapped in patterns of alcohol and drug addiction that destroy parenting capacity. I note the evidence showing that neglect has the same kind of devastating and lifelong impact on children as abuse, and is even as likely to cause death. ${ }^{18}$ This understanding of the neglect problem is key to my analysis of the promise and the problems inherent in various child welfare reform proposals. Thus, I criticize certain reforms promoted by family preservation advocates, in part because they are premised on an assumption that neglect cases are, overwhelmingly, minor cases that can be categorized as "dirty house" or "mere poverty" cases, and therefore should be diverted out of the official state system for addressing child maltreatment. I devote a significant amount of discussion throughout the book to the central role neglect cases play in the child maltreatment problem. ${ }^{19}$ All of Chapter 9 and much of Chapter 3 address alcohol and drug addiction, which are typically categorized as neglect rather than abuse, and which I claim lie at the very heart of the current maltreatment

\footnotetext{
14 See, e.g., id. at 95-97, 102-10, I 18-2 I.

15 See id. at $118-20$.

16 See id. at 97, 109-10, 120-2 1, 263 n.130, 266 nn.20-23, 269-70 nn.1 I-15.

17 See Guggenheim, supra note $\mathrm{I}$, at 1730 nn.67-69 \& 72. Recent research indicates that there is no evidence of success even in these limited terms. See, e.g., BARTHOLET, supro note I, at 120.

18 See BARTHOLET, supra note I, at 67, 253 n.3 I.

19 See, e.g., id. at 6I-67, I 50-5 I, I96-98.
} 
problem. ${ }^{20}$ Taken as a whole, the book mounts a significant challenge to what I call the safety mantra of the day. ${ }^{21}$

Astonishingly, Professor Guggenheim describes Nobody's Children as a book that wrongfully focuses on abuse as the central problem. ${ }^{22}$ He argues that $I$ fail to make out my case that children are at such risk in "abuse" and "safety" terms as to warrant my proposals for state intervention. ${ }^{23}$ He misses the basic thrust of the case I make. I believe that we must take seriously the neglect cases that family preservation advocates treat as marginal, and that we should not buy into their claim that the only cases worthy of child welfare agencies' attention are the abuse and safety cases.

\section{NAME-CALLING: RACIAL GENOCIDE, TOTALITARIANISM, AND THE EXPLOITATION OF POOR PEOPLE}

Early in my book I discuss the importance of attempting open and honest debate about the race and class issues that dominate policy in the child welfare area. I talk about the name-calling, and the fear of name-calling, that I think has silenced debate and paralyzed potential change agents. ${ }^{24}$ I recognize that many people of good faith and longstanding commitment to important social causes believe in the family preservation policies that I criticize. ${ }^{25}$ I analyze the politics that has led so many on the left to support family preservation, and I argue for a new political understanding of child welfare and child maltreatment issues. I draw an analogy to issues involving battered women, around which a new political consciousness has emerged that recognizes the risks that "family privacy" and "family preservation". pose to women victimized by family violence, and the benefits inherent in liberation

20 See id. ch. 3, at 67-81 ("Substance Abuse: At the Heart of the Problem"); id. ch. 9, at 207-32 ("Substance Abuse").

21 See id. at $196-98$.

22 See, e.g., Guggenheim, supra note 1 , at $1732-33,1737-38$.

23 See, e.g., id. at $1718,1725,1728,1733$.

24 See BARTHOLET, supra note 1 , at 5 (" Race and class issues dominate policy in this area, although the issues are rarely addressed honestly in a way that illuminates for onlookers their power. Change is impossible unless we can face up to the issues. Debate has been silenced, and potential actors paralyzed, by fear of opening up wounds and triggering rage, fear of proposing or taking action which would victimize already victimized groups, and fear of being accused of racism and classism.").

25 See id. ("Addressing these issues is not easy. In the first place, the answers are not easy. Many smart people who have committed their lifetime careers to civil rights, or poverty rights, or children's rights, or to making the child welfare system work, are convinced that the kind of family preservation policies challenged in this book are appropriate policies. They think we should do better by poor families and their children, but they are suspicious of using child removal or adoption except in the most extreme cases. These people obviously care deeply about improving children's lives, and they are convinced that family preservation policies serve that purpose, even if the current system leaves much to be desired."). 
from certain families. I warn that taking the positions I do will "trigger claims that you are promoting racial genocide, and that you have deserted the war on poverty for the new war on the poor."26 I argue that those who take my position on family preservation issues and who see themselves as liberals, committed to racial and social justice, should speak out, even at risk of being called nasty names, rather than leaving it to conservatives to speak up for victimized children: "[U]nless liberals join with conservatives to promote children's interests, there will be no real change."27

So I am not surprised that Professor Guggenheim engages in what I view as name-calling. But I am disappointed, because it simply gets in the way of the genuine debate on the issues that is needed.

Guggenheim describes me as "advancing a program of 'racial genocide.'”28 I take very seriously and discuss at length the racial implications of arguing for limits on what I characterize as family preservation excesses, for increased use of the adoption alternative, and for elimination of barriers to transracial adoption. Although both sides in this debate often accuse the other of racism and worse, I do not see these labels as helpful here. There are good reasons why people committed to racial justice end up on different sides of the debate. I do think it is helpful to recognize that the children victimized by abuse and neglect are disproportionately children of color, and to ask whether they as well as their parents should not be seen as having civil and other rights. In my book I explain why I conclude that the family preservation policies I challenge do devastating harm to children of color without in any way advancing the interests of adult communities of color. I leave it to those interested in these issues to read for themselves. ${ }^{29}$

Guggenheim also accuses me of promoting "totalitarianism." $30 \mathrm{He}$ claims that I show no respect for our nation's tradition of family privacy $^{31}$ and no concern for the dangers of "aggrandizing state power." 32

\footnotetext{
26 Id.

27 Id. at 6.

28 Guggenheim, supra note $I$, at 1723.

29 See, e.g., BARTHOLET, supra note 1 , at 4-6 ("The Race/Class Problem"); 123-40 ("Community Preservation: Race Matching and Related Policies"); 233-34 ("Race, Poverty, and Historic Injustice"); see also ELIZABETH BARTHOLET, FAMILY BONDS: ADOPTION, INFERTILITY, AND THE NEW WORID OF CHILD PRODUCTION 86-I I 7 (1999) ("Adoption and Race"); Elizabeth Bartholet, Private Race Preferences in Family Formation, I07 YALE L.J. 235I (1998); Elizabeth Bartholet, Race Separatism in the Family: More on the Transracial Adoption Debate, 2 DUKE J. GENDER L. \& POL'Y 99 (I995); Elizabeth Bartholet, Where Do Black Children Belong? The Politics of Race Matching in Adoption, 139 U. PA. L. REV. 1163 , 1201-26, 1232-38 (1991).

30 See Guggenheim, supra note I, at $\mathrm{I} 742$.

31 See id. at $1742-43$.

32 Id. at 1734 .
} 
He implies that I advocate removal of children based on little more than poverty ${ }^{33}$ or a "best interests of the child" standard. ${ }^{34}$

I do argue for a marginal shift in the state's willingness to intervene in families based on evidence that children are being severely abused and neglected. We should be as suspicious of claims of family "privacy" and "autonomy" when the rights of victimized children are at issue as we have grown to be when the rights of battered women are at issue. ${ }^{35}$ I am acutely conscious of the risks inherent in increasing state power over the family, but I conclude for reasons spelled out in the book that the benefits to children make the risks worth taking. ${ }^{36}$ As any reader of Nobody's Children will discover, my standard for removal is not a "best interests" standard, but an egregious abuse or neglect standard, and it would of course not permit removal of children based on poverty alone. When parents are so caught up in drug and/or alcohol addiction that there is a complete absence of affirmative parenting, and the children are at risk for devastating mental and emotional damage as well as physical harm, the state should intervene. And in cases of physical torture, the state should not only intervene, but also consider prompt termination of parental rights so that the children can move on to a permanent adoptive home and have a chance to heal.

Guggenheim's review relies on a series of mischaracterizations to give the impression that I promote a program for the removal of children from poor people - people he claims I view as unimportant - to give them to the rich and privileged. ${ }^{37}$ I do argue that we should not systematically eliminate from consideration for foster and adoptive parenting all but a limited group of prospective parents who come from the same racial group and live in the same geographic community as the children victimized by abuse and neglect. These children come disproportionately from the poorest communities in our society, communities in which many adults struggle for survival. Child welfare agencies have had increasing difficulty over the past decades finding adequate numbers of fit families to provide foster and adoptive homes for the children in need, in significant part because of the priority put on placing each child within its own kinship or racial group and within its own neighborhood. We need to look to a larger prospective parent pool for the children in need. In addition, I believe

33 See id. at 1718 (suggesting that I believe that "children deserve to be raised in conditions that many families currently cannot provide"); 1744 (claiming that I advocate "a policy that would treat families without means differently from families with means").

34 Id. at $1734, \mathrm{I} 746$.

35 See BARTHOLET, supra note 1 , at 8, 50-54, 243.

36 See id. at $236-37,243$.

37 See, e.g., Guggenheim, supra note I, at $1720,1738,1741$. 
that the entire community - not just a narrow racial and kinship group - needs to develop a sense of responsibility for all the children in the community if we are to address the problems of social and economic injustice with which Guggenheim and I are both concerned. But arguing for expansion of the adoptive parent pool is not equivalent to arguing that abused and neglected children be placed within a narrow slice of the population defined by privilege. I simply want to eliminate the rigid kinship, race-matching, and geographic preferences that currently limit the adoptive parent pool for most of the children in foster care to a narrow slice of the population defined by deprivation, and thereby lock many children into inadequate foster homes. I want to recruit rather than to reject families from the great mass of lower and middle class families that, as Guggenheim well knows, have always provided the overwhelming majority of eager adoptive applicants.

Guggenheim claims that "it is never clear precisely" what I mean by my title phrase "Nobody's Children," and that I must mean "the children of nobody particularly important," ${ }^{38}$ children of "parents who are without political influence."139 I spell out the meaning of my title in the first two paragraphs of the book in language that I trust readers will have no trouble understanding:

This book is about the children who are growing up without true families - without, that is, families that are functioning to provide the kind of care and nurture that is essential to well-being. It is about children born to parents who are themselves the products of inadequate parenting, of poverty and unemployment, of drugs and alcohol, of violence at the hands of their mates or of strangers. It is about black children and white children, Latino, Native American, and Asian children. It is about children growing up in homes in which they are physically brutalized or sexually exploited. It is about children born damaged by the drugs and alcohol their mothers used during pregnancy, children in need of very special parenting to overcome the damage, who are sent home to parents whose first love is their drug. It is about children who grow up parenting themselves and their siblings as best they can because the adults in their home are not mentally or emotionally capable of parenting. This book is about the children left to grow up in inadequate homes, but also about the children removed only to be placed in inadequate foster or institutional care. It is about those who will spend the rest of their childhood in state custody, and about those who will spend it bouncing back and forth between foster care and their homes of origin. These are Nobody's Children.

This book is also about the culture that makes it possible to see children as Nobody's, or Somebody Else's, and certainly Not Ours. It tells the story of how our child welfare policies came to place such a high value on

\footnotetext{
38 Id. at 1738 n.108.

39 Id. at 1738 n.108.
} 
keeping children in their families and communities of origin without regard to whether this works for children. It envisions a new culture in which the larger community assumes responsibility for the well-being of its children, a culture in which we understand children born to others as belonging not only to them, and not only to their kinship or racial groups, but to all of us. ${ }^{40}$

My point is that all too many children today are growing up effectively parentless. They are "Nobody's Children" in the sense that neither their parents nor the larger community are assuming responsibility for their care and upbringing. I of course agree with Guggenheim that the birth parents to whom he refers in the title of his review are indeed somebodies deserving of more than they now receive in the way of sympathy, help, and political influence. But I do not think that our sympathy for these somebodies should lead us to sacrifice the next generation of children by allowing them to be victimized by abuse and neglect, nor do I think that the kind of family preservation excesses that I criticize contribute to alleviating poverty or promoting racial justice for the disadvantaged groups about whom he and I both care. We have to stop treating birth parents and racial groups as having a possessory right to "their" children, and start treating children as having a right to be parented in a way that enables them to grow up healthy and sane. We have to look to the entire community to ensure that children get the parents they need. Lest Guggenheim be again mystified as to the meaning of my title, this is why I call my Reply "Whose Children."

\section{Family Preservation IN NEW ClothING}

Much of Nobody's Children is devoted to a critique of current proposals to reform the child welfare system being promoted by family preservation traditionalists. In the few pages Professor Guggenheim devotes to the topic, he condemns my approach without addressing my core arguments. ${ }^{41}$ I direct interested readers to Chapter 6, "New' Programs Promote Traditional Ideas," in which I discuss at length the most important of these new initiatives, including Community Partnership programs and Family Group Decision Making. ${ }^{42}$ Here I simply note my agreement with Guggenheim that these programs could be useful to the extent that they simply involve the provision of additional support for vulnerable families and communities. Guggenheim misses the point central to my critique of these programs, which is that at their heart they are designed to divert from the state intervention

\footnotetext{
40 BARTHOLET, supra note $I$, at $1-2$.

41 See Guggenheim, supra note I, at I 747--49.

42 BARTHOLET, supra note I, at I4I-59; see also id. at 28, 240-4I.
} 
system a huge range of cases that the proponents of these programs characterize as minor cases of maltreatment. For reasons spelled out in the book, I fear that most of these cases involve the kind of egregious neglect, typically involving serious substance abuse problems, over which the state needs to maintain jurisdiction so that it can, in appropriate cases, use coercive intervention to protect children from maltreatment, to require drug treatment as a condition for continued parenting rights, and to remove children and terminate parenting rights as necessary.

\section{REALISM AND REFORM}

Professor Guggenheim charges me with proposing a program that is not only wrong-headed but also unrealistic. ${ }^{43}$ In Nobody's Children I predict that "[s]keptics will say that the kind of program suggested is hopelessly impractical," 44 and I argue that this kind of assumption "is grounded in another assumption: that the child welfare system won't change the way it functions." 45 I believe that the system can change, and I lay out in the book numerous concrete proposals for change, which Guggenheim ignores. For example, in Chapter 8, "Taking Adoption Seriously," I discuss various promising developments including Concurrent Planning and Expedited Termination of Parental Rights, and in Chapter 9, "Substance Abuse," I discuss promising family court drug programs.

However, I recognize that in Nobody's Children I am proposing a significant shift in policy priorities that would require a related shift in cultural attitudes:

All this would take a huge change in the cultural mindset of those within the child welfare system, most of whom still believe that children belong in some essential way in their families and communities of origin. But cultural mindsets can change. We no longer assume that battered women belong in their homes. Outside the child welfare world attitudes about abused and neglected children seem to be changing, and there is increasing recognition of the idea that parenting is more about bonding than about blood. We need to bring new ways of thinking into the child welfare world . . . .46

It is not easy to change cultural mindsets. But in the area of child maltreatment, it is important that we try.

\footnotetext{
43 See Guggenheim, supra note I, at I 744-46. Guggenheim makes up figures on his own for the number of children that would need "immediate adoption" if my proposals were to be implemented $-200,000$ at one point, id. at 1719 , and "several hundred thousand" at another, id. at $1721-$ and then attributes these figures to me. See id. at I 7 I9 \& n.14, I 72 I.

44 BARTHOLET, supra note I, at 240.

45 Id. at $24 \mathrm{I}$.

46 Id. at $242-43$.
} 